\title{
AZ ÚJ TECHNOLÓGIA ÉS A TANULÁS VILÁGA A PSZICHOLÓGUS SZEMÉVEL
}

\author{
PLÉH CSABA ${ }^{1}$ - FARAGÓ BOGLÁRKA² \\ ${ }^{1}$ Közép-Európai Egyetem Kognitív Tudományi Tanszéke, Budapest \\ ${ }^{2}$ Eszterházy Károly Főiskola Pszichológia Tanszéke, Eger \\ E-mail:vispleh@ceu.edu; faragobogi89@gmail.com
}

Beérkezett: 2015. október 05. - Elfogadva: 2015. november 20.

\begin{abstract}
A pszichológia számos aspektusból vizsgálja az IKT- (információs és kommunikációtechnikai) eszközök hatását; például pozitív vagy negatív következményeit kapcsolati hálóinkra, motivációra és olyan kognitív folyamatokra gyakorolt befolyását, mint a figyelem vagy az emlékezet. Ez az áttekintö dolgozat e változások kereteit foglalja össze. A pszichológia az ember IKT-használatának jellemzőit próbálja feltárni, figyelembe véve az IKT által prezentált információ feldolgozásában az emberi észlelés korlátait is. A figyelemmel kapcsolatban fontos kiemelni a megosztott figyelem hatását, amely bizonyos körülmények között elösegíti, más esetben korlátozza az információ megfelelő feldolgozását, és a multitasking jelenséggel kapcsolatban is elötérbe kerül, csakúgy, mint a figyelem automatikusságának kérdése, amely az IKT-eszközök gyakori használatával kapcsolatban is releváns kérdés lehet. Az IKT-eszközök használata az emberi emlékezet számos összetevöjét (procedurális, prospekív, szemantikus stb.) befolyásolja, és hatására megjelenik a referenciális információelsajátítási mód, vagyis az információhoz való hozzáférés módjának eltárolása magának az információnak a tárolása helyett. Emellett az IKT-eszközök hozzáférést biztositanak egyfajta kiterjesztett memóriához, az ebben való eligazodáshoz viszont az embernek ki kell fejlesztenie egy sajátos készséget, a keresést és az azzal kapcsolatos deklaratív tudást. Ezen eszközök használatának extrinzik és intrinzik motiváló eröi meghatározhatók, amelyek jutalomként jelennek meg az IKT-használat következtében. Végül az IKT-eszközökkel kapcsolatosan nem megkerülhetöek a szociokognitív vonatkozások, hiszen ezen eszközök visszahatnak az emberi közösségre, további fejlödésre sarkallják az egyént, társadalmi változások indikátorai lehetnek.
\end{abstract}

Kulcsszavak: IKT-eszközök, figyelem, emlékezet, motiváció, szociokognitív hatások

Dolgozatunkban azt próbáljuk megmutatni, hogy milyen általános átalakulást eredményez az emberi gondolkodásban az állandó webhasználat, s ez milyen következményekkel jár az erre vonatkozó pszichológiai kutatásokra. 


\section{EMBEREK, GÉPEK ÉS ARCHITEKTÚRÁK}

Az európai gondolkodás történetében három különböző elvontsági szinten jelenik meg emberek és gépek viszonyának értelmezése.

A gépek megjelenése instrumentális váltást eredményezett. A gépek maguk új tudásokat testesítenek meg, és ezáltal kibontakoztatják az emberi képességeket. Közismertek erre a különböző munkaelméleti metaforák, a marxizmustól kezdve, amelyek az emberré válás folyamatában hangsúlyozzák a szerszámok használatának szerepét (Kardos, 1958, 1959). Ezek a gondolatok a mai összehasonlító lélektanban újra megjelennek mind az emberré válásra vonatkozóan, mind a kultúra korai fejlődésére nézve. A kulcskérdés, hogy hogyan kapcsolódik össze az eszközhasználat a társas tanulással, majd a konvencionalizációval, az eszközként használt tárgyak funkcionális fixációjával (Gergely és Csibra, 2005; Tomasello, 2014). A kanalak, kések, villák például meghatározzák a gyermek számára, hogyan eszünk, az eszközben mintegy kódolva van egy tudás és egy viselkedésmód, ahogy a Vigotszkij-iskolát e szempontból elemzi Yasnitsky és Ferrari (2008).

A gépek - sajátos eszközszerepük mellett - átalakitják egész életünket is. Az (első) ipari forradalommal radikálisan megváltozott energia-háztartásunk és a helyváltoztatásunk. A vasút, majd a távíró és a drótnélküli távíró, a rádiózás megjelenésével a közlekedés s a hírek közlekedése legyőzte a távolságot, és ez alapvetóen megváltoztatta életünket.

A harmadik elem a metaforikus mozzanat. A gépek egyben átalakítják azt a módot, ahogyan magunkról gondolkozunk. A telefon hatására megjelenik a telefonközpont metafora, akár már Pavlov munkáiban is, s Wolfgang Köhler (1929) már az 1920-as években ezt kritizálja, mint téves metaforát, s egy dinamikusabb, az energetikai folyamatokat előtérbe helyező képpel javasolja felváltani.

Az 1. táblázat e három felfogást mutatja be.

1. táblázat. Három felfogás a gépek szerepéről, példákkal a számítógépekre

\begin{tabular}{|l|l|l|l|}
\hline \multicolumn{1}{|c|}{ Koncepció } & \multicolumn{1}{|c|}{ Determináció iránya } & $\begin{array}{l}\text { Tudományos és köznapi } \\
\text { számítógépes példa }\end{array}$ & \multicolumn{1}{c|}{ Hálózati világ } \\
\hline Instrumentális & $\begin{array}{l}\text { A komputer megtestesíti } \\
\text { s algoritmizálja a gon- } \\
\text { dolkodást. }\end{array}$ & $\begin{array}{l}\text { Erôs mesterséges intelli- } \\
\text { gencia. } \\
\text { Szövegszerkesztővel ke- } \\
\text { resés. }\end{array}$ & Google-keresés \\
\hline $\begin{array}{l}\text { Életmód- } \\
\text { determinista }\end{array}$ & $\begin{array}{l}\text { A számítógép átalakítja } \\
\text { életünket. }\end{array}$ & $\begin{array}{l}\text { Tomográfia, űrhajózás. } \\
\text { Gépírás, számlázás. }\end{array}$ & $\begin{array}{l}\text { Könyvtár és in- } \\
\text { ternet. }\end{array}$ \\
\hline Metaforikus & $\begin{array}{l}\text { A számítógép átalakítja, } \\
\text { komputációssá teszi me- } \\
\text { taforáinkat. }\end{array}$ & $\begin{array}{l}\text { Az elme és az idegrend- } \\
\text { szer mint komputációs } \\
\text { modell. } \\
\text { Gépiesnek érezzük éle- } \\
\text { tünket. }\end{array}$ & $\begin{array}{l}\text { Csomópontok } \\
\text { vagyunk egy há- } \\
\text { lóban. }\end{array}$ \\
\hline
\end{tabular}


Mi is történt a számítógépes korszakban és mi történik a hálózati számítógép kialakulásával? A számítógépek kétségtelenül átalakították a tudományos pszichológiát. Nehézkesen magyarázzuk diákjainknak, hogy a mi szakmánkban a számítógépes képernyős megjelenítés és a klaviatúrás válaszadás előtt például a szófelismerés meghatározóinak vizsgálatához diakeretbe írt vagy fotózott szóingereket készítettünk, a bemutatáshoz külön ingervezérlőt kellett előállítanunk, s egy fényképezőgép-blende irányította a kivetítési időket, míg egy másik konzol rögzítette a válaszidőket. Ma mindezt egy PC-n futó szoftver megoldja.

Jelen kötetben több vizsgálatot is talál az olvasó az új technológiák kognitív pszichológia módszertanára gyakorolt hatásáról, így az emlékezeti terjedelem (számterjedelem, téri terjedelem és munkamemória-feladatok) számítógépes mérésével (Faragó és Kovács [pp. 127-141]; valamint Kovács, Faragó, Kövi, Rózsa és Dávid [pp. 73-90]), illetve az adaptív IQ-teszteléssel (Kovács és Temesvári [pp. 143-163]) kapcsolatos eredményekről.

A számítógépek köznapi gyakorlatainkat is megváltoztatták: míg a zsebórák, karórák, utcai és szobai órák elterjedése révén a 19. és 20. században megváltozott a pontosság, a hálózatos rendszerek következtében már nem az összehangolás, vagyis a pontosság lett a tét, hanem belépett életünkbe az állandó rendelkezésre állás, s ezzel sokunknál az azonnali reagálás kényszere. Ez zaklatottabb világot jelent mind az állandó bemenet oldalán, mind a kevésbé mérlegelt válaszok révén, a kimeneti oldalon is. A másik oldalon viszont a távhozzáférés révén sok minden vált könnyebbé: a menetrend megnézésétől kezdve a könyvtári keresésig s a hozzáférhető tudásbázisok megalkotásáig alapvetően átalakult az információhordozókhoz való hozzáférés. Ugyanakkor mindezek keretében a számítógépek s a hálózatok átalakították önképünket is. Elkezdtünk mind filozofikusan, mind köznapi értelemben szoftver- és hardveranalógiákkal gondolkodni magáról az emberről (Pléh, 1990), majd a szimbolikus tőke szerepét a kapcsolati tőke gondolkodásmódja vette át a Bourdieu (1978) által bevezetett fogalmakat használva.

Emellett a távolsági hálózatok előtérbe kerülése kételyeket is ébreszt bennünk. Pszichológiai kételyeket arra nézve, hogy az állandó kommunikáció, a hálózatokban való élés egyrészt nem túlzottan technologizál-e a személyes hálókhoz képest, másrészt nem oldja-e túlzottan fel az egyéni felelősséget, vagy az individuális mérlegelést és az individualitást.

\section{AZ EMBERI MEGISMERÉS ARCHITEKTÚRÁI AZ ÚJ IKT VILÁGÁBAN}

A mai kognitív tudomány a számítógépes metaforából kiindulva architektúrákon viszonylag stabil elrendezéseket ért. Olyan lassan változó rendszereket, amelyek mintegy az ácsolatát, a keretét adják meg az emberi gondolkodásnak (Pléh, 2013a). Evolúciósan ezek lassan alakulnak ki, kulturálisan lassan változnak és viszonylag stabilak. Egy részük egyedfejlődésileg is viszonylag lassan alakul ki. A látás és a nyelv kibontakozása például hosszú évekig tart. 
A képzetek, érzések, kifejezések, gondolatok mind ezekbe a rendszerekbe rendeződnek. Jellegzetes példája ennek a sokféle formában megfogalmazott kétféle emlékezeti rendszer, ahol megkülönböztetünk

- egy átmeneti, korlátozott teherbíró képességű, gyors működésű, rövid lejáratú emlékezeti rendszert, valamint

- egy tartósabb, lassabb működésű, ugyanakkor a gyakorlatban korlátlan kapacitású emlékezeti rendszert.

A két rendszer feltételezésére van szükségünk például a nyelvi teljesítmények magyarázatában is, ahol egy konkrét beérkező mondatot a tovatűnő, gyorsan változó rövid lejáratú emlékezeti rendszer kezel, azonban oly módon, hogy a szavakhoz és szabályokhoz a hosszú lejáratú rendszerből fér hozzá. Ugyanígy a rövid lejáratú rendszer őrzi meg az épp csak 10 másodperce látott ember arcát, ám a hosszú lejáratú rendszerben keressük a választ arra, hogy ki is ez az ember, ez az ismerősnek tűnő arc.

Az emberi architektúrák jellegzetes szintjei a személyhez és a személyes átéléshez való tartozás szempontjából különíthetők el. Ennek van jelentősége a mai információs eszközök tekintetében, tehát érdemes egy kicsit jobban belegondolnunk, hogy melyek a személy alatti, a személy szintjéhez tartozó és a személy feletti szerveződések. Ezeket összegzi a 2. táblázat.

2. táblázat. Az emberi architektúrák szintjei

(Newell, 1989 nyomán, módosítva)

\begin{tabular}{|l|l|l|l|l|}
\hline \multicolumn{1}{|c|}{ Szint } & \multicolumn{1}{c|}{$\begin{array}{c}\text { Kognitív } \\
\text { jellemzók }\end{array}$} & \multicolumn{1}{|c|}{ Idői sáv } & \multicolumn{1}{c|}{$\begin{array}{c}\text { Megvalósító } \\
\text { kategória }\end{array}$} & \multicolumn{1}{c|}{ Alapja } \\
\hline Szelf alatti & nem tudatos & $500 \mathrm{~ms}$ alatt & neurális hálók & evolvált neurális \\
\hline Szelfszintű & tudatos & $800 \mathrm{~ms}-$ évek & személy & $\begin{array}{l}\text { agykérgi integ- } \\
\text { ráció }\end{array}$ \\
\hline Szelf feletti & $\begin{array}{l}\text { nem tudatos-tu- } \\
\text { datos }\end{array}$ & mp-évek & társas kapcsolatok & $\begin{array}{l}\text { evolúciós alapú } \\
\text { interakció }\end{array}$ \\
\hline
\end{tabular}

Az architekturális rendszerek sajátosan befolyásolják, hogy milyen típusú leképezéseket, milyen reprezentációkat tudunk egyáltalán kezelni. Reprezentáción itt egyszerűen azokat a tudáscsomókat értjük, amelyek éppen rendszerszerűségük révén bizonyos következményekkel múködnek. A téri tudás például sajátos téri viszonyokat hoz mintegy „ingyen magával”, a nyelvi tudás sajátos szemantikai viszonyokat. Ha azt mondom például, hogy Feri látott egy kutyát, ebből következik annak igazsága, hogy Feri látott egy állatot, hiszen a kutya a szemantikai kategóriák rendszerében állat. Ez az adott mondatnál 'ingyen kapott' szemantikai viszony. Ha viszont azt mondom, hogy $A$ kutya az asztal alatt van, a macska pedig az asztal tetején ül, akkor ebből a téri viszonyok rendszere révén következik az a tudás, hogy a macska a kutya felett van. 
A mai világban megjelenő technológia indukálta változások lényegi mozzanata az egyéni tudáshordozás, a közösségi tudás s a hozzáférési mód megváltozása. Donald (2001a, b) közismert gondolatmenetét kiterjesztve a mai világra itt világosan három szakaszról van szó a memória külsővé tételében, s a külső memória „tulajdontalanításában".

1. A külső memória megjelenése az írás-olvasás rendszerében 10000 évvel ezelőtt. Ez a Donald (2001a) értelmében vett elméleti kultúra.

2. A gutenbergi kultúra. Tömeges reprezentáció terjedése az elméleti kultúra demokratizációjával 500 éven át. Russell (1976) fogalmazta meg az ismertség és a leírás révén való tudás kettőségét. Ebből a szempontból az írás-olvasás rendszere a leíráson alapuló tudások átadásának jellegzetes másodlagos felvételt eredményező közege. A Gutenberg elindította világban ez a másodlagos felvétel fokozatosan általánossá válik az olvasás és a közoktatás összekapcsolásával, de az elő́llítás és közvetítés még kontrollált, cenzoroktól szerkesztőkig.

3. A hálózati kultúra. Korunkra az elméleti kultúra reprezentációinak, a szövegeknek a könnyű átadása mellett az elsődleges orális és vizuális reprezentációk tömeges terjedése jellemző. Mind a felvétel, mind az elóállítás profanizálódik, s időtől s helytől függetlenedik. Az utóbbi nemzedékben (30 év) a másodlagos oralitás s a képek tömegterjedése révén technológiai kerülő úton visszajutunk a Donald-féle elméleti kultúra előtti helyzetbe (Nyíri, 1994).

A kiinduló folyamat lassú volt, mint Donald (1997, pp. 362-363) is megfogalmazta.

„Az emlékezet külsővé válása kezdetben igen fokozatos volt, az első állandó külső szimbólumok feltalálásának köszönhetően. Azután felgyorsult azonban, s a ma rendelkezésre álló külső megjelenítő eszközök nagy száma megváltoztatta azt, ahogyan az emberek felhasználják biológiailag adott kognitív erőforrásaikat, azt, hogy mit képesek tudni, hol tárolják ezt a tudást, s milyen kódokra van szükség annak kinyomozásához, hogy mi is tárolódott [...]. Milyen lenne a tudomány, ha egészen más kultúrán alapulna, mint a mi írásos kultúránk? Az az igazság, hogy erre nem tudjuk a választ, de jó lenne megismernünk, mert [...] az emberi kognitív rendszert nemcsak az öröklés befolyásolja, hanem saját egyedi kulturális története is."

Hunt (2012) a mai intelligenciakutatás egyik klasszikus képviselöje egyenesen azt hirdeti, hogy az értelmesség társadalmi és nemzetek közötti eltérései elsősorban azzal kapcsolatosak, hogy mennyire alkalmazzák a közösségek a különböző kognitív „artefaktumokat” a feladatmegoldásra. Ezeknek ő két típusát különíti el. A fizikai artefaktumok az írástól a GPS-rendszerekig terjednek, a mentális architektúrák pedig az írástudástól a törvényeken s a logikán keresztül a bankrendszer szervezéséig.

A mai kommunikációs tudáshordozók világában a drámai eltérések lényege Newell rendszerezésére átfogalmazva az, hogy a szelf alatti szintnek új eljárásai 
alakulnak ki, például igen gyorsan ugrálunk ablakok és weboldalak között, s eközben a szelf feletti rendszer protokolljai, a társadalmi elvárások is drámaian megváltoznak, miközben a pesszimisták szerint a tudatos szelfszintủ feldolgozás háttérbe szorul.

Az új elemeket a 3. táblázat illusztrálja.

3. táblázat. A tudásszerzés és -tárolás hagyományos és mai mintázatainak jellemzői

\begin{tabular}{|l|l|}
\hline \multicolumn{1}{|c|}{ Elméleti kultúra } & \multicolumn{1}{c|}{ Hálózati kultúra, új érzékiség } \\
\hline Évtizedekig leíráson alapuló szervezett tanulás & Kevesebb leírás, több séma és kép \\
\hline Lassú hozzáférés & Gyorsabb hozzáférés \\
\hline Elvont & Szenzuális \\
\hline Körülményes hozzáférés & Megosztott tudás \\
\hline Tudástulajdonlás & Közösségi tudás \\
\hline Felülről lefelé átadás & Horizontális (kortársak közötti) átadás \\
\hline
\end{tabular}

Az információ-hozzáférhetöségben drámai változások vannak. A klasszikus teoretikus kultúra világában az ember kénytelen volt elmozdulni az információtároló helyekre. Számtalan könyvtárba mentünk, a könyvtárakban fizikailag meg kellett fognunk a könyveket, s csak később, az utóbbi néhány évtizedben tudtuk egyáltalán lemásolni őket. Ebben a klasszikus időben a tudáshordozó birtoklási tárgy volt, s a hordozó fizikai nálam megléte kiemelt tényezővé vált. Emiatt azután a könyvből, cikkből feljegyzéseket, e feljegyzések alapján egy emlékezeti sémát készítettünk, és ezekből vizsgáztunk, ezekből írtuk cikkeinket. A tudáshordozó ritkasága s értékhordozó volta révén egyénivé, sajáttá tettük a tartalmát, mind abban a tekintetben, hogy újrareprezentáljuk, a külső leképezést belsővé tesszük, s közben át is alakítjuk (Sperber, 2001), mind abban az értelemben, hogy a mienké is lesz, ami másé volt, egyénített módon dolgoztuk fel az anyagot.

\section{A WEBVILÁG GONDJAI}

A mai posztteoretikus világban az ember állandóan mozog, és egyre inkább arra törekszik, hogy az IKT révén minden tudáshoz állandóan hozzáférhessen. A fiatal nemzedék számára szinte nem is létezik, ami nem digitalizált. Hasonló ez a folyamat ahhoz, mint amikor az írásbeliség átvette az orális kultúra helyét. Akkor a szelfhez képest külső volt a tárolás, de meghatározott helyeken, ezért szelfszintű feldolgozásához e kitüntetett helyekre, könyvtárba, iskolába kellett mennem. Ma viszont időben és térben is a teljes hozzáférhetőség felé haladunk és a teljes hozzáférés felé. Ma az eszmény az, hogy az elméleti kultúra információi mindenütt $\mathrm{s}$ mindig rendelkezésre álljanak a szelf számára. Ennek következtében azonban maga az állandó külső-belső leképezés közti átvitel is átalakul. Ha minden mindig hozzáférhető a külső rendszerben, akkor nem kell saját jegyzetekbe s a fejemben 
érvényes tudásba áttennem. A véghasználónál lényegileg „ingyen” megjelenő virtuális tudásinformáció könnyen szellemi rágógumivá válik. Ezen azt értjük, hogy háttérbe szorulhat az a relevanciát megteremtő diskurzus, amely a klasszikus leíráson alapuló tudások értékelését kísérte. A relevancia keresése és a következtetési folyamatok, mint Mercier és Sperber (2011) érvelnek mellette, elsősorban személyközi helyzetben teremtődnek meg. A túl könnyű hozzáférés ezt az interperszonális keretben végbemenő érvelő gondolkodást nehezíti meg.

A másik mozzanat a feldolgozással kapcsolatos belső változásokat érinti. „Szövegek tengerében fürdünk. Emellett a képek tengere is körülvesz bennünket, és az állandó hozzáférhetőség hatására megjelenik az elterelhetőség, a megbízhatóság, a többszörös feladatvégzés problémája. Ez állandóan felveti, hogy vajon egy ősibb állapothoz térünk-e vissza a képiség előtérbe állításával, ahogyan Nyíri Kristóf (2002; Nyíri és Szécsi, 1998) sokszor hangsúlyozza" (Pléh és mtsai, 2014, p. 695).

A nagyfokú vizualitás megjelenése a vizualitás következtében formaalapúvá váló keresés (nem az erszényes kategóriát, hanem a kenguru szót keresem), és egyáltalán a keresési ugrálások következménye. A feldolgozás könnyen válik pusztán haszonelvűvé, ahol elvész a magamévá tétel lépése. Ez utóbbihoz kapcsolódik a harmadik mozzanat: az IKT állandó bekapcsoltsági állapotában a többszörös feladatvégzés is az állandó felszínes feldolgozás fenyegető veszélyét hozza magával, illetve az önjutalmazó átkapcsolásokat, új megerősítési elrendezések s ezzel függőségek kialakulásának veszélyét. Mindez számos társadalmi pesszimizmus megfogalmazásához is vezetett.

Az átalakulások közepette megjelent a társadalmi borúlátás. Vannak szerzők, akik igen részletesen elemzik, hogy milyen veszélyeket rejthet magában ez az állandó kereséssel foglalkozó, weben lógó világ. Susan Greenfield (2010), brit idegtudós elősorolja, hogy melyek is a közvetlen következményei az információtechnológián alapuló tudásszerzésnek. A neves oxfordi agykutató nem túl optimista. Jelszava, hogy a tartalom helyett az Új Világban a folyamatra helyeződik a hangsúly, az állandó keresési váltásokban előtérbe kerül a felszínes feldolgozás. Ugyanakkor hiányzik mindaz (például a testnyelv, a szemkontaktus stb.), ami a természetes pedagógia része lenne. Olyan veszélyhelyzet áll elő, hogy az IKT nevelte nemzedék az állandó itt és most világában él, minden információ után újabb információra vágyik, és ezért csak klikkelget ide-oda. Mindez a múltbeli és jövőbeli mozzanatok háttérbe sorolását eredményezi (Pléh, 2011).

A hagyományos európai értelemben vett egyéniség és személyiség, a mérlegelő szelf, az individualitás helyett megjelennek egy passzív lény kialakulásának feltételei, aki a pillanatnyi élmények világában, csupán az input áradatára reagál. Greenfield szerint ez azt is jelenti (s nem biztos, hogy ebben igaza van), hogy alacsony szintű kontrollfolyamatok alakulnának ki a homloklebeny elülső részében, amiről régóta tudjuk, hogy a tervezés, az értékek, a viselkedéses gátlás és szabályozás legfontosabb helyszíne az agykéregben. Mit is lehet tenni? Greenfield szerint olyan pedagógiát kell kialakítanunk, amely átszervezi az információtechnológia által segített feldolgozást. Arra kényszeríti a fiatalokat, hogy csak akkor kattintsanak új oldalra, hogyha valamilyen szemantikai alapú feldolgozást végeztek a régi 
oldalon. Greenfield szerint az alapvető probléma az, hogy nemcsak képek özönében élünk, hanem a képek helyett szöveget olvasva is csak a szöveg szó szerinti részére vagyunk kíváncsiak, nem megyünk bele a szöveg szemantikai feldolgozásába.

Jabr (2013) nagy vitát kiváltó népszerűsítő összegzésében arra mutat rá, hogy a papíron olvasás már a könyv fizikai jellegzetességei, jobban áttekinthető elrendezése, a megvilágítási viszonyok és a haladás állandó jelzése - hol is vagyok a könyvemben - miatt is fölényben van a képernyővel szemben.

Amerikában egy másik Greenfield, Patricia Greenfield (2009) a pedagógiai pszichológia szempontjából tekinti az internethasználat gondjait. Abból az általában is megdöbbentő tényből indul ki, hogy Amerikában az utóbbi néhány évtizedben a gyerekek verbális intelligenciahányadosa javult. Ezt azzal tudjuk összekapcsolni, hogy valójában a szókincs fejlődésére pozitív hatása volt a televíziónak. Ezzel szemben áll az a paradox hatás, hogy az egyetemi felvételi a SAT verbális pontszámainál csökken a teljesítmény. Ennek oka, hogy a vizuálisan szocializált, a vizuális tanulásra hangolt fiatalság csak az alapvető szókincsében fejlődik. A verbális intelligencia vizsgálatokban olyan kérdéseket tesznek fel, hogy Mi a közös elem abban, hogy narancs és banán, aminek kapcsán azt kell megtalálni, hogy déligyümölcs. Ugyanakkor az önálló, örömszerző olvasáson alapuló fejlettebb szókincsre az egyetemi felvételi anyag sokkal érzékenyebb. Az egyetemi felvételiken már olyan kérdéseket tesznek fel, hogy Mi a különbség a kielégült és kielégitett szavak jelentése között. Az ekkor tapasztalható alacsonyabb teljesítmény, az önálló, irányítatlan, örömért folyó olvasás hiányát tükrözi. Jelen kötetben szintén szerepel egy vizsgálat az IKTeszközöknek a generációk közötti intelligencia változására gyakorolt hatásával kapcsolatban (Kovács és Temesvári, jelen kötet, pp. 143-163).

Patricia Greenfield (2009) összefoglalt számos olyan vizsgálatot is, amelyek azt mutatják ki, hogy az információtechnológia hatására megjelenő nagyobb megosztott figyelem azt is eredményezi, hogy sokkal nehezebben tudunk beszámolni arról, hogy mit is tanulunk. A hírek alatt futó szalaghíreket olvasó, figyelmüket megosztó személyek például kevesebbet tudnak arról, hogy mi volt az eredeti, képernyőn elhangzott vagy látott hír. Az olvasásnak - mondja Patricia Greenfield - igazából fontos szerepe van már az iskoláskorban, már a közoktatás világában is. Az olvasás az egyetlen olyan médium, amely állandóan megkívánja a reflexiót. Ennek megfelelően nem meglepő, hogy az iskolában is a jobban olvasó, a többet olvasó gyerekek kevésbé impulzívak és sikeresebbek az induktív feladatok megoldásában már az alsó tagozatban is. Másfél évtizeddel későbbre ugorva, az egyetemistáknál az olvasás alapvetően a kritikai gondolkodást segíti, és ennek megfelelően társadalmunk és kultúránk kriticista értékeinek megtartását.

Clay A. Johnson (2012) The Information Diet című művében az evéssel és evészavarokkal állítja párhuzamba információfogyasztásunkat, és annak diszfunkcióit. Szerinte a sikeres „információs diéta” alapja a tudatos információfogyasztás, vagyis az, hogy tisztában vagyunk vele, milyen információt fogyasszunk, mely információkat kerüljünk el, tudjunk szelektálni. Emellett a helyes információfogyasztás nem beszúkült, csak a meggyőződéseinket támogató információ keresését jelenti, hanem széles körủ keresést a minket érdeklő témával kapcsolatban, amely a miénkkel ellentétes vélemények megfontolását is magában foglalja. 


\section{AZ ÚJ IKT PSZICHOLÓGIAI KÖVETKEZMÉNYEI}

A megjelent új technológiák következményeit nemcsak a társadalmi átfogó újítás és aggodalmaskodás keretében tekinthetjük azonban, hanem az érintett pszichológiai mechanizmusokra nézve is. Röviden rendszerezzük ezeket a hatásokat tanulási, emlékezeti, figyelmi, motivációs és kommunikációs szempontból.

\section{A tanulás terepei és az új technológia}

A hagyományos képhez képest, amely az iskolai tanulást állítja középpontba, a tanulásnak legalább három különböző terepe van (Pléh, 2013b). Valóságos tanulások az utcai készségek elsajátításai is, a villamosozástól a viccelődésig, vannak azután az általában vertikális tudásátadáson alapuló, a mi kultúránkban hagyományos tanultató iskolai helyzetekre épülő tudásátadások, de mind a gyermekek, mind a felnőttek világában vannak jellegzetes horizontális, egyenrangúak közti tudásátadásra építő, mégis szervezetten ismétlésesen kialakuló tanulási terepek is.

A mai világban is újra központivá válik e három tanulási terep viszonyának értelmezése. E hármas viszony megértésében sokféleképpen szoktunk megfogalmazni. Az egyik megfogalmazás Ernst Rothkopftól, a mai pedagógiai pszichológia egyik legjelentősebb, 2012-ben elhunyt módszeradó vezéralakjától származik. Rothkopf (2008; Shaughnessy, 2005) rendszerezte, hogy mi is történik a 21. század elején abban a három típusú tanulási helyzetben, amiről az előzőekben beszéltünk. A három rendszer Rothkopf megkülönböztetésében: a nyílt rendszerek, a bolti termékek és a zárt rendszerek. Ezek a rendszerek eltérő módon tanultatnak meg, s értelmezésükkor nagyon eltérő dilemmákat vetnek fel mind a pedagógia, mind a pszichológia számára. A bolti rendszerek állandóan megjelennek a nyitott rendszerekben. Nyitott rendszereknek Rothkopf érdekes és provokatív módon éppen az iskolát nevezi. A bolti rendszerek nagy problémája és feszültségteremtő ereje az, hogy sokszor igen laza kritériumokkal próbálják irányítani a meglévő, Rothkopf által nyitott rendszereknek nevezett rendszerek működését. A 4. táblázat a három rendszert a saját optimális működésében mutatja be.

4. táblázat. A tanulás három terepe Rothkopf (2008) elemzésében

\begin{tabular}{|c|l|l|l|}
\hline $\begin{array}{c}\text { Tanulási } \\
\text { terepek }\end{array}$ & \multicolumn{1}{|c|}{ Fő jellemző } & \multicolumn{1}{|c|}{ Példa } & Fejlesztési kritériumok \\
\hline Nyílt & $\begin{array}{l}\text { Általános célok, tanuló } \\
\text { kliensek, közösség választ, } \\
\text { közösség és tanuló fizet. }\end{array}$ & Iskola, főiskola, egyetem. & $\begin{array}{l}\text { Kánon (például NAT). } \\
\text { Nem túl kellemetlen, } \\
\text { fenntartható. }\end{array}$ \\
\hline Bolti & $\begin{array}{l}\text { Tanuló választ. } \\
\text { Tanuló fizet. }\end{array}$ & $\begin{array}{l}\text { Nyerjünk pókerben. } \\
\text { Szerváljunk jobban. }\end{array}$ & $\begin{array}{l}\text { Nincs nagy hiba. } \\
\text { Kellemes, olcsó. }\end{array}$ \\
\hline Zárt & $\begin{array}{l}\text { Intézmény választ. } \\
\text { Intézmény fizet. }\end{array}$ & $\begin{array}{l}\text { IBM, NASA, hadsereg- } \\
\text { tréning. }\end{array}$ & $\begin{array}{l}\text { Minimális idő, } \\
\text { költséghatékony. }\end{array}$ \\
\hline
\end{tabular}


Rothkopf szerint a mai kor nagy pedagógiai lélektani dilemmája, hogy sok erő igyekszik a hatékonyság nevében a nyílt rendszert zárttá, illetve boltivá tenni. Megjelennek a bolti mozzanatok a nyitott rendszerben (legyen csupa öröm az egyetem), ugyanakkor a bolti kritériumhiánya miatt ez nehezen vezet bárhova is. A zárt rendszerek világos kritériumelemzése nehezen vezethető be a nyílt rendszer egészébe. Pedig vannak törekvések, például az egyetem iparosítására, de ezek inkább csak feszültséggenerálásra jók. A járható út Rothkopf (2008) szerint az, ha olyan eljárásokat vezetünk be, amelyek kutatásokra alapozzák a tananyag átadását, s magát az oktatást teszik hatékonyabbá, nem lépésenkénti mérésre törekszenek.

Az internet tanulási használatát is összekapcsolhatjuk a tanulási terepek elemzésével. A tananyag elsajátításának a helyszínei ma összefonódnak a technológiai újításokkal. Mason és Rennie (2008) a formális és informális tanulást állítják szembe egymással. Míg az előbbi később is hozzáférhető tudást eredményez, az utóbbi az adott pillanatban történik és csak azonnal hasznosítható tudáshoz vezet. Ez utóbbihoz tartozik a szerzők szerint a webes tanulás is. Viszont mivel az informális - webes - tanulás egyre inkább általánossá válik, hozzá kell segíteni a tanulókat ezen eszközök adaptív használatához, valamint fejleszteni kell a kritikai gondolkodás képességét bennük. Ganesan (2007) szerint a tanulási rendszerek és a technika kombinációjával létrejött e-learning rendszerek magas szintű integrált tanulást tesznek lehetővé, emellett szinte bárhol és bármikor hozzáférhetőek, és gazdagabb tanulási környezetet teremtenek, mint amit az osztálytermi környezet nyújtani képes.

Voltaképpen arra lenne szükség, hogy a web segítette tanulás kérdését beilleszszük abba a klasszikus, szervezett tanulást érintő elemzésbe, ami az olvasásprelegálás tantermi s valós gyakorlati viszonyát illeti. Ennek modern pragmatikus, gyakorlás elvű formája Dale sokat hivatkozott s sokat bírált elemzése (1946/1969), amit az 1. ábra mutat.

A százalékok megőrzést jelentenek, s részleteikben szakterülettől függően sokat vitatottak. Masters (2013) metaelemzése például az orvosképzésre mutatja ki, hogy a részletek sokban megalapozatlanok. Az IKT tekintetében arra lenne szük-

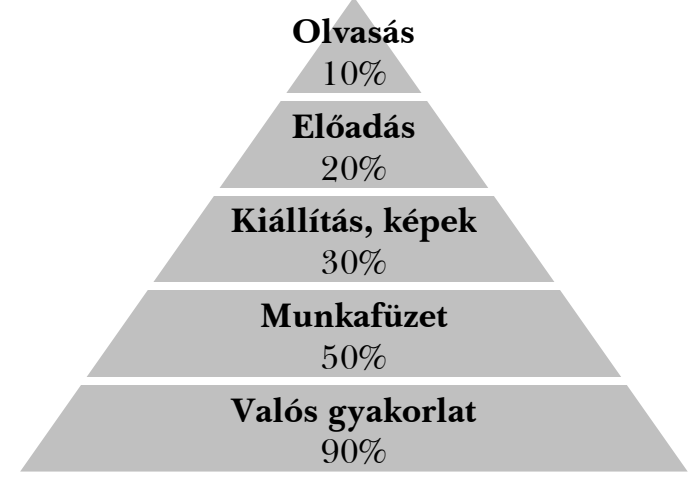

1. ábra. Dale (1946) elemzése a tanulási eljárások megőrzési hatékonyságáról 
ség, hogy különböző területeken (például történelem, fizika, biológia), életkorokban s eljárásokkal (órai webhasználat, okostelefonos feladatok, önálló webfeldolgozás, digitális tananyag) valós adatok alapján töltsük fel ezt a piramist.

Jelen kötetben az IKT-eszközöknek a tanulás közvetlen közegében való megjelenésével kapcsolatban három vizsgálat is olvasható; az egyik az IKT-eszközöknek az iskoláskori kognitív működésekre gyakorolt hatását mutatja be (Dorner, Hatvani, Taskó, Soltész, Estefánné Varga és Dávid [pp. 25-56]); a második az iskoláskori tanulási stratégiák elemzésével (Dávid, Dorner, Hatvani, Soltész, Taskó és Soltész-Várhelyi [pp. 165-195]), míg a harmadik az önszabályozó tanulással foglalkozik (Dávid, Taskó, Héjja-Nagy, Mester, Dorner és Estefánné Varga [pp. 197205]).

\section{Emlékezeti keresés és az új IKT}

Tudásforrásaink és az emlékezeti keresés mindig sajátosan kapcsolódtak. Nemcsak az írott emlékezeti anyagokra, például könyvekre, kőtáblákra gondolhatunk itt, hanem a körülöttünk élő személyekre is. Például amikor tudjuk, hogy egy bizonyos rokonunk a család minden tagjának születésnapjára jól emlékszik, akkor elég, ha őt megkérdezzük, és elég, ha ezt az információt (vagyis, hogy kihez forduljunk bizonytalanság esetén) idegrendszerünkben tároljuk. Az emlékezeti előhívás ugyanakkor egy olyan mentális folyamat, amely, ha az emléknyom megszilárdult, viszonylag automatikusan és gyorsan zajlik. Ezzel szemben ahhoz, hogy a számunkra releváns információkat megszerezzük az interneten keresztül, olyan procedurális tudással kell rendelkeznünk, amely képes a kívánt információt az információtömegből kiválasztani.

Ez a procedurális tudás a keresés, amelyet akár egy új, az ember és IKT-eszköze között zajló emlékezeti folyamatként is értelmezhetünk, egy viszonylag új jelenség az ember emlékezeti folyamatai sorában (Wegner és Ward, 2013). A keresók világa (a Google-világ) új külső memóriaként jelenik meg. Ennek hatására lehetséges, hogy csökken a belső memória szerepe. Megnő a figyelemmegosztás lehetősége és jelentősége. Magabiztosabbá válunk tudásainkban, hiszen állandóan hozzáférhetővé válnak a tartalmak.

Gyakori a webmotorokkal történő keresés. Nielsen (2008) szerint a rendszeres webfelhasználók - mivel gyakrabban használják az internet keresési funkcióját is ismerik a keresés használatának alapjait, általában jó kezdő keresési kulcsokat használnak, viszont ha ez a kezdő kulcsszó nem az általuk várt eredményt hozza, kevésbé jók a keresési stratégia megváltoztatásában. Az átlagos felhasználók a keresés eredményének interpretálásában sem jeleskednek a szerző szerint, hiszen általában a legelső megjelenő linkre kattintanak, ez viszont gyakran nem az, amire valóban szükségük van. Jackson (2008) szerint az öt- vagy több éves online tapasztalattal rendelkező amerikaiak 60\%-a nincs tisztában azzal, hogy az internetes keresők algoritmusok szerint működnek, ahol a többet linkelt és a fizetett oldalak kerülnek az első keresési eredmények közé. Mason és Rennie (2008) szerint az internet tele van válogatás nélküli információval, és a legtöbb diák nem rendelke- 
zik megfelelő kritikai készséggel, amely az információk szelektálásához elengedhetetlen.

Ugyanakkor keresésfüggővé is válhatunk. Tartalom helyett folyamatokra koncentrálunk, talán másképp is olvasunk. Saját hiteink ezek hatásáról érdekes mintázatot eredményeznek. Nasi és Koivusilta (2013) rámutatnak arra, hogy van, aki szerint az egyéni memóriát növeli, s van, aki szerint csökkenti a keresőmotorok világa. A fiatalok szerint inkább növeli, s az idősebbek szerint inkább csökkenti. A többet netezők inkább csökkenni érzik a memóriát a kevesebbet netezőkhöz képest. Ami a memóriarendszereket illeti, Sparrow, Liu és Wegner (2011) kutatásai szerint, ha laboratóriumi körülmények között imitáljuk a Google-keresést, és olyan helyzeteket teremtünk, ahol bizonyos feladatmegoldásokat elmenthetnek a kísérleti személyek, illetve nem menthetnek el, akkor arra, amit elmentettek, kevésbé fognak emlékezni. Van tehát egy olyan hatás, hogy az emlékezeti rendszerekben hajlékonyabbá tesznek a rendelkezésre álló hálózati kereső rendszerek.

Amikor ismerőseinktől, tanárainktól próbálunk információhoz jutni, ők hatékonyan tudnak segíteni abban, hogy pontosan mire is vagyunk kíváncsiak, a keresőmotorok kevésbé tudnak ebben segíteni, ha nem ismerjük a megfelelő keresőszavakat. A keresés tehát kifinomult készség. Ezzel kapcsolatban érdekes azt a jelenséget is megemlíteni, amely a szociálisan és az interneten is elérhető tudásokkal kapcsolatban kialakult. Nyilvánvaló, hogy a szociálisan megszerezhető információk egy része az interneten is elérhető, és az is nyilvánvaló, hogy a kérdezett személy erőforrásainak használata számára költséges lehet (meg kell szakítania gondolatmenetét, előhívnia a másik által kért információt, és a másik számára érthető módon közölni azt), ezért alakulhatott ki az a kifejezés, hogy: A Google a barátod! (Google is your friend!). Amikor a kérdezett személy ezt mondja, arra kéri a kérdezőt, hogy az ő személyes erőforrásai helyett a bőségesen rendelkezésre álló és egyénileg olcsó IKT-kapacitást használja. Ebben a jelenségben megmutatkozik az, hogy a más személyeken keresztül tárolt információ a kérdező számára nagyon kis erőforrásigénnyel elérhető, ha a másik jelen van, szemben a kérdező erőfeszítésével, amit a számítógéphez leülve egy keresőmotor használatával kell kifejtenie. Azon képességünk, hogy milyen hatékonyan vagyunk képesek kiterjeszteni memóriánkat az IKT-eszközökkel, azon múlik, hogy a keresési hatékonyságunk, az azzal kapcsolatos procedurális (hogyan kell használni) ismereteink milyenek (Sparrow, Liu és Wegner, 2011).

Ahhoz, hogy hatékonyan keressünk, szükségünk van nemcsak a keresőmotorok használatához kapcsolódó procedurális tudásra, hanem a konkrét információval kapcsolatos területspecifikus tudásra is. Minél specifikusabb információra van szükségünk, annál nélkülözhetetlenebb a témával kapcsolatos konkrét saját szemantikus memóriában tárolt deklaratív tudás (deklaratívon az olyan tudást értjük, amelynek tudatában vagyunk), hogy megfelelő keresőkifejezést formulálhassunk, illetve hogy a keresési eredmények közül a releváns információkat kiválogathassuk. Az ilyen módon elérhető információkhoz való hozzájutás tehát igen idő- és erőforrás-igényes a személy számára. Sok pszichológus és médiakutató ezért aggodalmát fejezi ki a jelenséggel kapcsolatban. Ahhoz, hogy az információkat kombinálni tudjuk, így a különböző forrásokból származó tudást szintetizálni tudjuk 
például új tudás létrehozásához, elengedhetetlen, hogy ne egy monitorról olvassuk, hanem memóriánkban a szintetizálandó információkat egyszerre fel tudjuk idézni. Alapvető emlékezéssel kapcsolatos ismereteink alapján tudjuk, hogy a végrehajtó funkciók számára úgy tudunk nagy mennyiségű információt rendelkezésére bocsájtani, ha azokat az idegrendszer korlátozott bemenetére tömbökben adjuk át, a tömbök képzéséhez viszont az információt előzetesen elkülöníthető koherens csoportokba kell rendezni, amely az információ mélyebb feldolgozását, mélyebb ismereteket igényel a témakörrel kapcsolatban. Nemcsak a szintetizáló képességgel, hanem magával az emlékezési folyamattal kapcsolatban is aggodalmakat vetnek fel egyes kutatók. Érvelésük szerint az emlékezési folyamatok erőfeszítéstől való megkímélése nemcsak az emléknyomokat, hanem az emlékezési készségeket is rontja, vagyis, ha minden információt külső memóriamankókra bízunk, előbb-utóbb elsatnyul az a készségünk, hogy információkat kódoljunk a hosszú távú memóriánkba (Spitzer, 2012).

\section{Kommunikáció, tanulás és IKT-eszközök}

Valójában a legtágabb kérdés annak elemzése, mire is használjuk az IKT-eszközöket és a számítógépes hálózatot. Több magyar többváltozós vizsgálat is próbálta ezt tisztázni fiatal felnőtteknél. Külön kategóriaként megjelent már Csepeli és Prazsák (2010) 2008-as vizsgálatában a kommunikáció és tanulás mint az internethasználat egyik útja, valamint Krajcsi, Kovács és Pléh 2001-es vizsgálatában is, mint a levelezés-kommunikáció faktora.

Az internet kommunikációs céllal való használatához sorolhatjuk nemcsak az emailt, hanem a különböző közösségi oldalak használatát is. Johnson (2011) szerint az IKT-eszközök kitágítják a szociális hálónkat, így tágabb lehetőségeket teremtenek arra, hogy ötleteinket és élményeinket megosszuk egymással. Ezek az új eszközök már nemcsak a hagyományos azonos idö-azonos hely alapú kapcsolatoknak kedveznek, hanem az azonos idö-eltérö hely (például videokonferencia), az eltérö idöazonos hely (például hangüzenet) és az eltéró idö-eltérö hely (például e-mail, skype) kapcsolattartást is lehetővé teszik, ezáltal megkönnyítve az információk megosztását is (Fontaine és Cheen, 2008). Ezzel kapcsolatban az ember igen alkalmazkodó. Egy 2002-es magyar vizsgálatban többek között arra is keresték a választ, hogy milyen csatornákon kérünk információt más személyektől. Eredményeik szerint ilyen célra a leggyakrabban használt eszköz a vonalas telefon $(39,4 \%)$, ezt követi az internet $(29,8 \%)$, a személyes megkeresés $(17,0 \%)$, a mobil $(8,7 \%)$, az e-mail $(4,3 \%)$ és végül a csigaposta, azaz a hagyományos levél $(1,1 \%)$ (Kovács, Krajcsi és Pléh, 2002). Tehát az internetes megkeresés már ekkor is a második helyen állt a lehetőségek között.

Nem csak eszközeink folyamatos jelzései orientálják a figyelmünket időről időre az online tér felé, hiszen az állandó elérhetőség világában (Gitlin, 2008; Deresiewitz, 2009) elvesztettük a képességünket az egyedüllétre, azáltal érezzük a realitásunkat, hogy mások számára láthatóak vagyunk az online térben. Ez pedig igen megnehezíti ezen eszközök használatának korlátozását. 


\section{Motiváció}

A motivációval kapcsolatos egyik kérdés a hálózati eszközök másodlagos jutalomforrás szerepe. Ezzel kapcsolatban az e-mail és a szociális közegek (Facebook, Twitter) részleges megerősítő hatását érdemes kiemelni. Míg a hagyományos, papíralapú postát minden nap közel azonos időben hozza a postás, addig e-mail- $\mathrm{s}$ Facebook-üzenetet a mai eszközök révén bárhol és bármikor kaphatunk. Ez azt jelenti, hogy a klasszikus terminológiában változó intervallumú megerősítés jelenik meg (Ferster és Skinner, 1957), vagyis a megerősítés nem egy bizonyos időintervallum elteltével (ami a hagyományos posta esetén egy nap), hanem bármikor bekövetkezhet, függetlenül attól, mikor volt az előző megerősítés (Atkinson és mtsai, 2005). Ez azt eredményezi, hogy folyamatosan nézegetjük e-mail fiókunkat, várva a következő ,jutalomra”. Ezt kiegészíti a különböző IKT-eszközök konvergenciájának jelensége, amelyet Negroponte (2002) így fogalmaz meg: „Az egyes médiumok közötti határok elmosódnak, az eddig különálló médiumok összeolvadva, multimédia-termékek formájában új entitást hoznak létre, s végül is győzedelmeskedik a konvergencia.” Erre példa az okostelefon, amely már jelzi azt is, ha e-mailünk érkezett, vagy éppen közösségi felületünkön történt valami.

Ez a folyamatos megzavartság állapotában tart minket, ahogyan Jackson (2008) fogalmaz, folyamatos multitaskinghoz vezet. A multitasking során a figyelmünket ide-oda váltogatjuk a különböző feladatok végrehajtása között, jelen esetben erre példa, ha munka közben csipog a telefonunk, jelzi, hogy e-mailünk jött, és munkánkat félbehagyva már lépünk is fel e-mail fiókunkba elolvasni az üzenetet. A multitasking ugyanakkor mentális költségekkel jár, a figyelemváltás ugyanis csökkentheti feladatvégzésünk hatékonyságát.

A motivációval kapcsolatos másik kérdés az, hogy mi motiválja az egyes embert az IKT-eszközök használatára, illetve azok elkerülésére? Ennek megértéséhez az IKT-használattal kapcsolatos közvetett és közvetlen hasznosságokat kell számba vennünk. Minden közvetlen és közvetett hasznosság lebontható a személy számára közvetlenül, illetve a társadalmon, környezetén keresztül érkező jutalmazási rendszerekre. Közvetlenül a személy számára érzékelhető hasznosság egyrészről az eszközök által nyújtott tartalmak szórakoztató jellege, vagy olyan, a számítógéppel végezhető tevékenység, amely végzésére a személy intrinzik motivációt (Ryan és Deci, 2000) érez (más szavakkal, minden egyéb külső jutalom hiányában is végezné, mert élvezi és érdekli). Ilyen tevékenység gyakorlatilag bármi lehet, legegyértelműbb példái azonban az internetezés, illetve a számítógépes játék, függetlenül attól is, hogy egyébként a személy ezeket más tevékenységek elkerülésére vagy szabadidejében végzi. Közvetett hasznosságot hordoznak az olyan tevékenységek, és ilyenformán extrinzik motivációval hatnak a személyre (közvetített belső jutalmak, vagy külső jutalmak hatására végzi), amelyek az IKT-eszközök használata révén segítenek (1) a személy integritásának fenntartásában vagy növelésében, például vallásos, ideológiai, erkölcsi nézeteinek bővítésében, fenntartásában, ezzel kapcsolatos vélt vagy valós feladatainak elvégzésében (például Anna minden nap fellép a Facebookra és kitesz egy posztot, amely az állatok védelmével foglalkozik, mert így minél több embert érhet el ebben a fontos kérdésben). Másrészről (2) az identifi- 
káció révén, vagyis olyan célok érdekében való használat, amikor a személy valamilyen csoporthoz vagy eszméhez való tartozását szeretné kihangsúlyozni önmaga, vagy környezete számára (például Péter minden nap Minecraft játékkal játszik a számítógépén, mert felnéz Gáborra, aki sokat beszél Minecrafttal kapcsolatos játékélményeiről, és ekképpen is azonosulhat vele). Harmadrészt (3) introjektált értékek mentén való használatról is beszélhetünk: ilyenkor a személy belátja, hogy az IKT-eszköz valamely módon való használata számára előnyökkel fog járni hoszszú távon, például jobb munkaerő-piaci lehetőségei vagy potenciálja lesz, vagy valamilyen feladatokat gyorsabban, kisebb anyagi vagy idői ráfordítással tud végezni általában. Végül (4) közvetlen előnyök hatására, amikor a személy valamilyen büntetés elkerülésére (például meg kell írni a házi feladatomat, hogy ne kapjak elégtelent), vagy jutalom megszerzésére irányul (például fizetnek, ha begépelem ezt a szöveget).

A motivációk osztályozása mellett megfigyelhetünk IKT-használathoz kapcsolódó motivációs trendeket, amelyek az utóbbi évtizedekben jelentkeztek, és jellemzően hatnak a mai társadalom tagjaira. Ilyen bizonyos IKT-eszközök státuszszimbólumként való használata, az IKT-tudás munkaerő-piaci értéke és megbecsültsége, a szociális kapcsolatok ápolásának megkönnyítése és vélt vagy valós kiterjesztése, nemcsak a mobiltelefonok, de a szociális hálók (például Facebook, Myspace) alkalmazásával is, az IKT-eszközök használata során elérhető nyereségek (például olcsóbb külföldre telefonálni skype segítségével, webshopok árelőnye), ingyenesen és gyorsan elérhető információk, média, szórakoztatás eltolódása az internet felé stb.

\section{IKT-eszközök és szórakozás}

Az említett 2001-es magyar vizsgálatban az internethasználattal kapcsolatban talált harmadik faktor a szórakozásfüggőség volt (Krajcsi, Kovács és Pléh). Csepeli és Prazsák (2010) vizsgálatában talán ide sorolható a web 2.0 fókomponens (amelyben olyan összetevők szerepelnek, mint a zeneszámok, filmek letöltése, videoblognézés, blogírás, file-csere, filmnézés) és a szerencsejáték és szórakozás faktor.

Amennyiben a tanulásunk vagy munkánk környezete a számítógép, vagy a számítógép be van kapcsolva, miközben tanulunk, dolgozunk, elképzelhető, hogy „könnyebben elcsábulunk egy kis kikapcsolódásra”, hiszen csak egy klikkelésnyire van a pihenés. Az „elcsábulás” költségei csökkenhettek, mert alig kell viselkedéses erőfeszítést kifejteni az eléréséért (Kenyon és Lyons, 2007).

Johnson (2012) a diétával párhuzamot vonva azt javasolja, hogy olyan kontrollt alkalmazzunk az információfogyasztásunkban is, mint diéta esetén, vagyis a hütő kiürítéséhez hasonlóan szabaduljunk meg azoktól a zavaró tényezőktől, amelyek elvonhatják a figyelmünket a munkánkról, vagy a tanulásról; halkítsuk le a telefont, kapcsoljuk ki a számítógép jelzéseit, és csak bizonyos időnként engedélyezzünk magunknak kis szünetet az e-mailek ellenőrzésére.

Ugyanakkor Johnson is kiemeli, hogy a rövid időre történő „elcsábulás” munka vagy tanulás közben képes csökkenteni azt a magas kognitív terhet, amelyet a 
tanulási vagy munkatevékenység vált ki, így előnyös is lehet az ilyen szünetek beiktatása (2012). Vizsgálatainkban a multitasking cikkben mi is felmértük, milyen online kikapcsolódási formák jelennek meg főiskolás diákoknál tanulás közben (Kvaszingerné Prantner, Soltész, Faragó, Pléh és Soltész-Várhelyi, jelen kötetben [pp. 109-125]).

Számos olyan vizsgálat is van, amelyek közvetlenül megnézik, hogy mi történik a gyakran több feladatot (például mobiltelefonálás, e-mailezés, szemtől szembeni beszélgetés, előadás hallgatása stb.) végző személyeknél. Ophir, Nash és Wagner (2009) eredményei szerint azt a személyt, aki gyakorta végez egyszerre több feladatot, laboratóriumi körülmények között is jobban zavarják az elterelő ingerek.

Nicholas Carr (2010) népszerü könyvében részletesen elemzi, hogy a neten való élet valójában állandó elcsábíthatóságot és állandó intellektuális szétesettséget eredményez. Történeti párhuzamok vonásán keresztül vezeti le a tényt, amely szerint az internet valóban formálja gondolkodásunkat. Ilyen párhuzam Nietzsche írógépének története, amely megváltoztatta tulajdonosának írói stílusát, vagy a térkép és hordozható mechanikus óra elterjedése gondolkodásra gyakorolt hatásának leírása. Az olvasás történetében mintegy keretként jelentkezik a legkorábbi szövegek olvasására jellemző mély olvasási képesség hiánya (az írásjelek és a szavak elválasztásának hiánya miatt) és a mai, digitális világban szintén uralkodó - a digitális dokumentumok hipertext formája, a koncentrált figyelem hiánya miatt megjelenő - felületes olvasás közötti párhuzam.

Carr (2014) szerint „A technológia lármás fejlődése [...] elfojthatja azokat a kifinomult érzékeket, gondolatokat és érzéseket, amelyek csak a szemlélődés és az elmélkedés hatására jutnak felszínre" (p. 280). A papíron és monitoron történő olvasással kapcsolatban egy kutatásban vizsgáltuk a különböző felületeken megjelenő szövegek olvasási idejében, megértésében, memorizálásában mutatkozó különbségeket a megjelenítési felület függvényében (Kvaszingerné Prantner, Soltész és Jakub, jelen kötet [pp. 91-108]).

\section{Szociokognitív vonatkozások}

Közösségi hálózataink működése, jellege és a kommunikáció lehetőségei az evolúció során mindig összefonódtak. Az ember már kész közösségi működési készségeket és tendenciákat vett át őseitől, amelyek a túlélést segítették, ezekből indul ki az ember kiemelkedő kommunikációsképesség-repertoárja. Kezdetekben ez minimális technikai hozzájárulással társult (például bottal verve a fát távolra üzenni a veszélyt). Az ember megjelenésével a technika a kommunikáció javítására, időben és térben való kiterjesztésére, a kifejezni kívánt tartalmak pontosítására fordítódott. A fejlődés egy része az ember kifejezőkészségében (gesztikuláció, artikuláció, mimika) nem technikai vonatkozásaival, más része technikai vonatkozásaiban nyilvánult meg (festés, szobrászat, díszítés, ruházat).

A nyelv kb. 50-100 ezer éve alakult ki, ezt követően kb. 5 ezer éve jelent meg az írás, 600 éve a nyomtatás. Az internet széles körben kb. 15 éve kezdett elérhetővé válni, az első videó a Youtube-ra 2005-ben lett feltöltve, a Facebook pedig 
2004-ben startolt. Az ember által létrehozott IKT-eszközök mindig visszahatottak az emberi közösségekre, további fejlődésre sarkallták az egyént, társadalmi változásokat indítottak meg. Jogosan merül fel bennünk a kérdés, vajon átformálták-e szociális hálózatainkat az IKT-eszközök, és ha igen, hogyan.

Nyilvánvaló, hogy az IKT-eszközök által közvetített tartalmak érzelmeket közölnek, befolyásolják érzelmeinket. Két jelenséget azonban meg kell említeni, amely kiemelkedik e folyamatok közül. A szociokognitív vonatkozásokban említettük, hogy az új eszközök relevánsak saját kapcsolati hálónk építésében, arról is beszélnünk kell azonban, hogy ezeken az új médiumokon keresztül milyen affektív folyamatok zajlanak. A Facebook egy érdekes kísérletet végzett a felhasználók tudta nélkül (Kramer, Guillory és Hancock, 2013). Manipulálta mintegy 700000 felhasználója hírfolyamát, hogy azok inkább pozitív vagy inkább negatív információkat tartalmazzanak (kiszürte azokból a negatív vagy pozitív kommenteket), ennek eredményeképpen a felhasználók inkább pozitív vagy inkább negatív tartalmú saját posztokat fogalmaztak meg. A kutatók szerint tehát a „társas érzelmi fertőzés" valós jelenség, amely ilyen módon mindennapjainkat is befolyásolja.

Egy másik jelenség a társadalmi kérdésekkel, véleményekkel kapcsolatos polarizációhoz kapcsolódik. Clay A. Johnson Információs diéta címü könyvében (2012) rámutat arra a jelenségre, hogy a szubjektív értékítéletet, világnézeti, politikai hovatartozást érintő kérdésekben általában olyan információkat keresünk, amelyek megerősítik korábbi vélekedéseinket, aminek következtében a sok információ nemhogy szélesebb látókört eredményez, de mindinkább egyoldalú véleményhez vezet.

Emellett Johnson az információval kapcsolatos szokásainkat evolúciós keretben próbálja értelmezni. Véleménye szerint, ahogyan a korábban szűkös erőforrásnak tekinthető ételek könnyű, olcsó elérhetősége elhízási járványhoz vezetett, ugyanúgy a korábban szűkösnek tekinthető információforrások kibővülésével sem tudunk mit kezdeni, nem lép fel egy ösztönös korlát, amely azt sugallja, hogy ne „fogyasszunk” több információt, ahogyan a túlsúlyos emberekben sem alakul ki undor a túlzott kalóriabevitellel szemben. Ezért amellett érvel, hogy magunk számára kell korlátozni az információbevitelt a kiegyensúlyozott életvitelhez, ahogyan azt sokan a kalóriabevitellel is teszik, tudatosan vagy helyes szokásokon keresztül.

Ezek a szociokognitív vonatkozások ugyanakkor nem csupán szociális életünkre vannak hatással, hiszen a legtöbb ember minden tevékenysége, így a vizsgára készülés is szociális közegben zajlik. Vizsgálatainkban ezeknek a szociokognitív vonatkozásoknak a vizsgára készülésre gyakorolt hatását is elemeztük, így a vizsgára készülés közben fellépő vizsgaszorongást enyhítendő érzelmi megküzdési folyamatokat, amelyben a társas támogatás (például a másik személy sem áll olyan jól a felkészülésben, vagy „megtanulhatatlannak” tartja az anyagot) az új IKT-eszközökön keresztül is zajlik (Faragó, Soltész és Pléh, jelen kötet, pp. 57-72). Vizsgáltuk továbbá az IKT-használattal kapcsolatos idői, szociális és tanulási jellemzőket is 10-18 éves korosztályban is (Dávid, Dorner, Hatvani, Soltész, Taskó és Soltész-Várhelyi, jelen kötet [pp. 165-195]). 


\section{KÖSZÖNETNYILVÁNÍTÁS}

A kötet/tematikus szám dolgozatai javarészt az Eszterházy Károly Főiskola műhelyében készültek. A mủhely a Főiskola hosszú távú, a Hauser Zoltán korábbi rektor és Kiss Tóth Lajos elindította digitális oktatási elkötelezettségeit követik a pszichológia módszereivel. Anyagi forrásukat két TÁMOP, Társadalmi Megújulás Operatív Program adta, amelyek programmenedzsere Verók Attila volt. Mindhármuk segítségét köszönjük. A TÁMOP programok azonosítója: IKT a tudás és tanulás világában - humán teljesítménytechnológiai (Human Performance Technology) kutatások és képzésfejlesztés (TAMOP-4.2.2.C-11/4.2.2D), illetve Digitális átállás az oktatásban (TAMOP 4.2.2.D-15/1/KONV-2015-0027 azonosítószámú projektek keretében készült. A projektek az Európai Unió támogatásával és az Európai Szociális Alap társfinanszírozásával valósultak meg.

\section{IRODALOM}

Atkinson, R. C., Hilgard, E., Smith, E. E., Nolen-Hoeksema, S., Fredrickson, B. L., \& Loftus, G. R. (2005). Pszichológia. Budapest: Osiris Kiadó.

Bourdieu, P. (1978). A társadalmi egyenlötlenségek újratermelödése. Budapest: Gondolat Kiadó.

Carr, N. (2014). Hogyan változtatja meg agyunkat az internet? A sekélyesek kora. Budapest: HVG Könyvek.

Csepeli Gy. és Prazsák G. (2010). Örök visszatérés? Társadalom az információs korban. Budapest: Jószöveg Mủhely Kft.

Dale, E. (1946/1969). Audiovisiual methods in teaching. $3^{\text {rd }}$ ed. New York: Holt, Reinhart \& Winston.

Dávid M., Dorner L., Hatvani A., Soltész P., Taskó T. és Soltész-Várhelyi K. (2016). Az IKT hatása a kognitív működésekre iskoláskorban. Magyar Pszichológiai Szemle, 71(1), 165195.

Dávid M., Taskó T., Héjja-Nagy K., Mester D., Dorner L. és Estefánné Varga M. (2016). Az önszabályozó tanulás fejlettségének összefüggései a tanulási eredményességgel és az IKT-használat gyakoriságával Magyar Pszichológiai Szemle, 71(1), 197-225.

Deresiewitz, W. (2009). The End of Solitude. In M. Bauerlein (Ed.), The digital divide: arguments for and against Facebook, Google, texting, and the age of social networking (pp. 305-317). New York: Jeremy P. Tarcher/Penguin.

Donald, M. (1997). The mind considered from a historical perspective: human cognitive phylogenesis and the possibility of continuing cognitive evolution. In D. Johnson, \& C. Ermeling (Eds.), The Future of the Cognitive Revolution (pp. 478-492). Oxford: Oxford University Press.

Donald, M. (2001a). Az emberi gondolkodás eredete. Budapest: Osiris.

Donald, M. (2001b). A mind so rare. New York: Norton.

Dorner L., Hatvani A., Taskó T., Soltész P., Estefánné Varga M. és Dávid M. (2016). IKThasználat 10-18 éveseknél - Egy IKT-eszközhasználati kérdőív bemutatása. Magyar Pszichológiai Szemle, 71(1), 25-56. 
Faragó B., Soltész P. és Pléh Cs. (2016). Az IKT-használat jellegzetességeinek vizsgálata főiskolások körében. Magyar Pszichológiai Szemle, 71(1), 57-72.

Ferster, C. B., \& Skinner, B. F. (1957). Schedules of reinforcement. New York: AppletonCentury-Crofts.

Fontaine, G., \& Cheen, G. (2008). Presence in Teleland. In K. E. Rudestam, \& J. Schoenholtz-Read (Eds.), Handbook of online learning (pp. 30-56). London: SAGE Publications, Inc.

Ganesan, N. (2007). A Survey of Hardware and Software Technologies for the Rapid Development of Multimedia Instructional Modules. Journal of Educational Technology Systems, 36, 63-77.

Gergely, G., \& Csibra, G. (2005). The social construction of the cultural mind: Imitative learning as a mechanism of human pedagogy. Interaction Studies, 6, 463-481.

Gitlin, T. (2011). Nomadicity. In M. Bauerlein (Ed.), The digital divide: arguments for and against Facebook, Google, texting, and the age of social networking (pp. 207-214). New York: Jeremy P. Tarcher/Penguin.

Greenfield, P. (2009). Technology and informal education: What is taught, what is learned. Science, 323, 68-71.

Greenfield, S. (2010). Identitás a XXI. században. Budapest: HVG Könyvek.

Hunt, E. (2012). What makes nations intelligent? Perspectives on Psychological Science, 7, 284306.

Jabr, F. (2013). Why the Brain Prefers Paper? Scientific American, 309, 34-39.

Jackson, M. (2008). Distracted: The Erosion of Attention and the Coming Dark Age. New York, USA: Prometheus Books.

Johnson, C. A. (2012). The Information Diet: A Case for Conscious Consumption. Sebastopol: O'Reilly.

Johnson, S. (2011). The Internet. In M. Bauerlein (Ed.), The digital divide: arguments for and against Facebook, Google, texting, and the age of social networking (pp. 26-33). New York: Jeremy P. Tarcher/Penguin.

Kardos L. (1958). A nyelv eredete és a munka. Filológiai Közlöny, 47, 539-551.

Kardos L. (1959). Tanulás és emberré válás. Pszichológiai Tanulmányok, I., 105-113.

Kenyon, S., \& Lyons, G. (2007). Introducing multitasking to the study of travel and ICT: Examining its extent and assessing its potential importance. Transportation Research Part A: Policy and Practice, 41(2), 161-175.

Kovács K., Faragó B., Kövi Zs., Rózsa S. és Dávid M. (2016). A rövid távú emlékezet és a munkamemória online mérése: Corsi, szám-terjedelem és N-vissza. Magyar Pszichológiai Szemle, 71(1), 73-90.

Kovács K. és Faragó B. (2016). A modern technológia hatása a kognitív képességekre: áttekintés Magyar Pszichológiai Szemle, 71(1), 127-141.

Kovács K. és Temesvári E. (2016). Számítógépes, adaptív IQ-mérés: egy gyakorlati példa Magyar Pszichológiai Szemle, 71(1), 143-163.

Kovács K., Krajcsi A. és Pléh Cs. (2002). Mobilhasználat, időgazdálkodás és extraverzió. In Nyíri K. (szerk.), Mobilközösség - mobilmegismerés: Tanulmányok. A 21. század kommunikációja (pp. 179-200). Budapest: MTA Filozófiai Kutatóintézet.

Köhler, W. (1929). Gestalt Psychology. New York: Liveright. 
Krajcsi A., Kovács K. és Pléh Cs. (2001). Internethasználók kommunikációs szokásai. In Nyíri K. (szerk.), A 21. századi kommunikáció új útjai (pp. 93-110). Budapest: MTA Filozófiai Kutatóintézete.

Kramer, A. D., Guillory, J. E., \& Hancock, J. T. (2012). Experimental evidence of massivescale emotional contagion through social networks. Proceedings of the National Academy of Sciences (PNAS), 111(24), 8788-8790.

Kvaszingerné Prantner Cs., Soltész P., Faragó B., Pléh Cs. és Soltész-Várhelyi K. (2016). A multitasking jelenség hatása a feladatvégzésre és az időbeosztásra - Módszertani előtanulmány. Magyar Pszichológiai Szemle, 71(1), 109-125.

Kvaszingerné Prantner Cs., Soltész P. és Jakub Á. (2016). A papírról és képernyőről való olvasás és a talpas, illetve talpatlan betűtípusok hatása az elsajátításra. Magyar Pszichológiai Szemle, 71(1), 91-108.

Mason, R., \& Rennie, F. (2008). Evolving Technologies. In K. E. Rudestam, \& J. Schoenholtz-Read (Eds.), Handbook of online learning (pp. 91-128). London: SAGE Publications, Inc.

Masters, K. (2013). Edgar Dale's Pyramid of Learning in medical education: A literature review. Medical Teacher, 35, 584-593.

Mercier, H., \& Sperber, D. (2011). Why do humans reason? Arguments for an argumentative theory. Behavioral and Brain Sciences, 34(2), 57-74.

Nasi, M., \& Koivusilta, L. (2013). Internet and Everyday Life: The Perceived Implications of Internet Use on Memory and Ability to Concentrate. Cyberpsychology, Behavior, and Social Networking, 16(2), 88-93.

Negroponte, N. ([1995] 2002). Digitális létezés. Budapest: Typotex Kft.

Newell, A. (1989). Unified theories of cognition. Cambridge: Harvard University Press.

Nielsen, J. (2008). User Skills Improving but Only Slightly. In M. Bauerlein (Ed.), The digital divide: arguments for and against Facebook, Google, texting, and the age of social networking (pp. 52-62). New York: Jeremy P. Tarcher/Penguin.

Nyíri J. K. (1994). A hagyomány filozófiája. Budapest: T-Twins.

Nyíri J. K. (szerk.) (2002). A XXI. század kommunikációja. Budapest: MTA Filozófiai Kutatóintézet.

Nyíri J. K. és Szécsi G. (szerk.) (1998). Szóbeliség és írásbeliség. Budapest: Áron.

Ophir, E, Nass, C., \& Wagner, D. (2009). Cognitive control in media multitaskers. Proceedings of the National Academy of Sciences Early Edition (PNAS), 5, 15583-15587.

Pléh Cs. (1990). A számítógép és a pszichológia. Világosság, 31, 527-541.

Pléh Cs. (2011). A WEBvilág kognitív következményei, avagy fényesít vagy butít az internet? Korunk, 28(8), 9-19. http://korunk.org/letoltlapok/Z_ZMKorunk201 laugusztus.pdf, Letöltve: 2015.11.20.

Pléh Cs. (2013a). A megismeréstudomány alapjai. Az embertól a gépig és vissza. Budapest: Typotex.

Pléh Cs. (2013b). A pedagógia és a pszichológia klasszikus és új kapcsolatai. Iskolakultúra, 23(5-6), 78-81.

Pléh Cs., Rácz A., Soltész P., Kardos P., Berán E. és Unoka Zs. (2014). A lélek a WEB világában: Kapcsolatok és tanulás az új IKT közegében. Magyar Pszichológiai Szemle, 69(4), 679-705.

Rothkopf, E. Z. (2008). Reflections on the field: Aspirations of learning science and the practical logic of instructional enterprises. Educational Psychology Review, 20, 351-368. 
Russell, B. (1976). Miszticizmus és logika és egyéb tanulmányok. Budapest: Európa.

Ryan, R. M., \& Deci, E. L. (2000). Self-determination theory and the facilitation of intrinsic motivation, social development, and well-being. American Psychologist, 55, 68-78.

Shaughnessy, M. F. (2005). An Interview with Ernst Rothkopf: Reflections on Educational Psychology. North American Journal of Psychology, 7, 51-58.

Sparrow, B., Liu, J., \& Wegner, D. M. (2011). Google Effects on Memory: Cognitive Consequences of Having Information at Our Fingertips, Science, 333, 776-778.

Sperber, D. (2001). A kultúra magyarázata. Budapest: Osiris.

Spitzer, M. (2012). Digitale Demenz. Wie wir uns und unsere Kinder um den Verstand bringen. München: Droemer Verlag.

Tomasello, M. (2014). A natural history of Human Thinking. Boston, MA: Harvard University Press.

Wegner, D. M., \& Ward, A. F. (2013). The Internet Has Become the External Hard Drive for Our Memories. Scientific American, 309(6), 22-23.

Yasnitsky, A., \& Ferrari, M. (2008). From Vygotsky to Vygotskian psychology: Introduction to the history of the Kharkov School. Journal of the History of the Behavioral Sciences, $44,119-145$.

\title{
NEW TECHNOLOGY AND THE WORLD OF LEARNING FROM THE PSYCHOLOGIST'S PERSPECTIVE
}

\author{
PLÉH, CSABA - FARAGÓ, BOGLÁRKA
}

Psychology investigates the impact of ICT (information- and communication technology) devices from many aspects; these new tools have both positive and negative effects, and they also study the impact of these tools on our social network, motivation and cognitive processes as attention or memory. This review paper summarizes the direction of psychological research in this area. Psychology trying to discover the human characteristics of ICT use, considers the limits of human perception in processing information presented by ICT devices. In line with attention we should emphasize the impact of split focus, which can facilitate, or in other circumstances restrict the correct information processing, and it is associated with multitasking, like the automation of attention, which could be relevant question in the case of frequent use of ICT devices. The use of ICT devices influences many aspects of human memory (procedural, prospective, semantic...) and leads to a referential mode of information acquisition, when we merely store the access route to the place of information, rather than the information itself. In addition, ICT devices give an access to a sort of extended memory. At the same time, people should develop specific skills of search, and connect its results to declarative knowledge. The use of ICT devices has explicit and implicit motivational factors, which appear like rewards because of the usage of these devices. Finally, we can't forget the sociocognitive impact of ICT devices, since these devices react to human community, they motivate people for further development, and they could be indicators of social changes.

Key words: ICT devices, attention, memory, motivation, sociocognitive impacts 